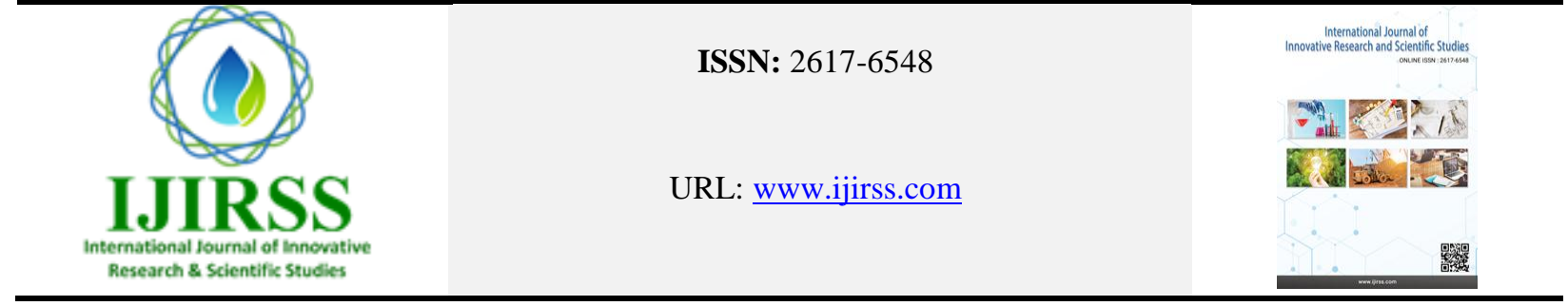

\title{
Strategies and Techniques for the Internationalization of Non-Dominant Firms: A Qualitative Study
}

\author{
Wilson Freddy Makaya ${ }^{1}$, (D) Chijioke Nwachukwu², (D) Vu Minh Hieu*
}

\author{
${ }^{1}$ Horizons University Paris, France. \\ ${ }^{2}$ Horizons University Paris and Department of Economics and Finance, South Ural State University Russian Federation. \\ ${ }^{3}$ Faculty of Business Administration, Van Lang University, Vietnam. \\ *Corresponding author: Vu Minh Hieu ( hieu.vm@vlu.edu.vn)
}

\begin{abstract}
This study focuses on the strategies and techniques used by small or medium-sized enterprises (SMEs) to join and dominate large firms in global markets. The analytical works refer to the prevailing writings on international markets and entrepreneurship. Based on the categorizations and analyses of the themes and sub-themes, the historical development of global markets and theories is recounted, thereby creating a foundation for assessing the strategies and techniques of nondominant firms. The findings indicate that the number of small and medium enterprises joining international markets is growing due to the adoption of robust strategies and techniques. An international model is proposed, which consists of three techniques of the Diaspora approach, social media approach, and re-approach, along with strategies that consist of three dimensions: a big dream or desire to internationalize, a need to internationalize, and an ability to internationalize." This paper provides a point of reference for practitioners and researchers interested in attaining comprehensive insight into internationalization.
\end{abstract}

Keywords: Non-dominant firms, Internationalization process, SMEs, Strategies, Qualitative study, Techniques.

DOI: 10.53894 /ijirss.v4i4.299

Funding: This study received no specific financial support.

History: Received: 8 November 2021/Revised: 13 December 2021/Accepted: 20 December 2021/Published: 29 December 2021

Licensed: This work is licensed under a Creative Commons Attribution 4.0 License $\left(\right.$ (c) EY $^{-}$

Acknowledgment: All authors contributed equally to the conception and design of the study.

Competing Interests: The authors declare that they have no competing interests.

Transparency: The authors confirm that the manuscript is an honest, accurate, and transparent account of the study was reported; that no vital features of the study have been omitted; and that any discrepancies from the study as planned have been explained.

Ethical: This study follows all ethical practices during writing.

\section{Introduction}

For many years, small, non-dominant firms have feared internationalization and still lack a strategy for such a development. Competing with other leaders in industry is necessary, but the process of internationalization is a strategy that can lead to the death of small firms [1]. Dominant organizations have many advantages, such as economies of scale, industrial standards, reputation, loyalty, and effective distribution channels [2]. For a non-dominant business to become international, they must take into consideration various business strategies such as having a reliable supply chain and marketing department, culture, language, and workforce. This means that non-dominant firms must invest huge resources 
to compete in international markets that are characterized by strong competition. According to Cavusgil and Knight [3], the basic methods utilized by most firms to enter the international market include contractual firms, foreign direct investment, exports, partnership, joint venture, etc. Non-dominant firms lack capital, management, and knowledge on internationalization, which are critical success factors [4]. Therefore, the successful international expansion of SMEs depends on their ability to develop opportunities and translate them into global business activities. By understanding both the factors working against them and those supporting their internationalization strategy, small firms can develop feasible frameworks. Considering the challenges facing the non-dominant business internationalization process, it is essential to develop viable approaches to ensure SMEs achieve success. The main problem that prompted this study is the increasing concern about how non-dominant enterprises can compete with industry leaders both at the local and international levels. This study describes how non-dominant businesses compete effectively with dominant leaders in international trade together with the factors that determine the success or failure of firms participating in international trades. Based on the perceptions of leaders (owners, managers, CEOs) of non-dominant firms, the authors attempt to enhance international business literature by seeking answers to the following questions:

- Which strategies do non-dominant SMEs use to expand internationally?

- What techniques do they use to mitigate the fierce competition from large corporations?

- What factors determine the success or failure of non-dominant firms in the international market?

Providing answers to these questions will enhance our understanding of the techniques and strategies required for the internationalization process of non-dominant firms. This study has the potential to contribute to the internationalization of non-dominant firms using smart techniques and strategies. The information gathered from the study can be beneficial for future decision-making in strategies and techniques for the internationalization of non-dominant firms.

\section{Literature Review}

\subsection{International Entrepreneurship Theory}

Zahra and George [5] describe international entrepreneurship as the advancement of the market in an alien world. Progressions in technology bringing reduced cultural barriers and increased cultural awareness have opened the door for localized firms to venture into foreign markets. International entrepreneurship involves the study of entrepreneurial activities focusing on global behaviors. The theory comprises the innovative and risk-taking behaviors that create value in foreign markets. Both company and individual behaviors are the essential aspects that facilitate entry to foreign markets [6]. Other factors, such as technological advancements and easy ways to send or access information, have also played significant roles in taking local business abroad. Stevenson and Jarillo [7] believe that the organizational value created by members enables entry into foreign markets through proactive, innovative, and calculated risk behaviors. They believe that the critical factor in internationalization is being an entrepreneur. The assertion, supported by Nwachukwu. and Vu [8], is that entrepreneurial leadership plays a key role in SMEs' performance in the marketplace. International new ventures (INVs) are closely related to the theory, and they pose several challenges. The theory ventures or embraces the profound perceptions of evaluation, enactment, and exploration of resources and opportunities to create innovative opportunism and sell goods and services [9].

\subsection{Overview of the Internationalization of SMEs}

Several authors have dissected aspects surrounding the internationalization of non-dominant firms to articulate their significance in the global economy (e.g., [4, 10, 11]). Lasserre [12] claims that small firms play a critical role in creating jobs, enhancing innovation, and boosting wealth in many countries. The paradigm shifts in the global business landscape, especially with the increase in globalization and the demand for rethinking strategies, value chains, and structures within non-dominant firms [10]. The firms must include a concept that revolves around the motive, market entry strategy, potential, and foreseeable obstacles [13,14]. One of the most critical enablers of this process is capitalizing on technology and innovation. Non-dominant firms must embrace technological development to increase their data sources and analytics, enabling them to make realistic decisions. Technology is also a vital platform for small firms to gain visibility and make accurate predictions concerning market trends. Brouthers, et al. [15] claim that technological advances are a critical source of competitive advantage. They enable small firms to have shorter product lifecycles, increase consumer convenience, and enhance their brand presence abroad. The use of social media is a good example of a vital factor that enables small firms to sell their products and services abroad while competing with dominant firms. Additionally, aspects like e-commerce make doing business in the international market less daunting [16]. Therefore, one of the critical factors small firms can leverage to enable their internationalization process is integrating technology into their business models. One of the most notable hypotheses posits that SMEs can develop international strategies that nullify the competitive advantages of larger firms. Direct competition with dominant firms can have adverse repercussions on a small firm's ability to operate at a global level. Fey, et al. [17] argue that one of the most plausible approaches in such a case is focusing on a specialty market segment that dominant firms can neither reach nor satisfy. Identifying a niche market is critical here since small firms can market and establish themselves as primary players before competition from large firms sets in. By serving a niche market, small firms capitalize on their resources to enhance their brand presence, increase consumer confidence, and hence develop customer loyalty [18]. They can also differentiate their products or services, thus forming a unique brand not found among other firms. Network knowledge enables small or non-dominant businesses to understand all the actors within the market [19]. The main reason for acquiring network knowledge is to understand how the business might be affected. In addition, to internationalize non-dominant businesses effectively, at least one exchange relationship is imperative. Another way SMEs can access unlimited international markets is by using trade promotion strategies. According to Martincus and Carballo 
[20], trade promotions such as temporarily reducing prices and using sampling techniques can help non-dominant firms to access international markets without having to incur huge expenses. Trade tariffs and barriers may hinder non-dominant businesses from thriving because dominant businesses already have enough influence to change market trends. However, by reducing prices temporarily and sampling products within the retail sector, non-dominant businesses can grow significantly within these markets.

\subsection{Foreign Market Entry Strategies}

The decision to enter an international market will depend on the nature of the company's scale [21], time, resources, obligations, and size. Below are some of the entry modes that companies chose [22]. Exporting is one of the best platforms to enable the future global expansion of a business. It is one of the most used strategies by SMEs, mainly because of the scarcity of resources. Turnkey projects involve two firms responsible for putting up a specific project in a particular country. Most organizations, especially in under-developed countries, hire contractors from abroad to develop specific planned projects [23]. Franchising is a process that involves distributing products and services using a franchisor, which establishes the brand's trade name and business system and pays the royalties and fees required. McDonalds is a franchising industry that sells goods and services in return for royalty payments [24]. A joint venture is formed by two firms that have come up with an agreement to work together. They combine resources and expertise to develop new products, thereby expanding into different markets and increasing operational activities [25].

\subsection{Strategies of the Non-Dominant Firms}

With improved factors that enable the growth and development of businesses, a market can go international. Dominant markets cause frustration for less prevalent firms - new firms that are also becoming internationalized need to monitor some strategies that other firms have used to succeed. Wood [9] identifies the below methods that firms have used to dominate international markets.

- Extension to less competitive primary markets. To fully manage international demands, firms need to quickly extend their products to competitive markets in other developed countries where buyers tend to buy at a price the same as the domestic one.

- Dissemination of technology. Most of these small firms tend to introduce their products to the developed market quickly. Most already internationalized firms have based their strategies on licensing and joint ventures even though they have limited resources. They try to capture maximum returns in a faster way. Their pattern of concentration is because of the technology change [26].

- Segmentation of markets. Localization has been the main idea behind most firms intending to capture international markets. They believe that the products they manufacture are always needed in other countries.

- Reconfiguration of traditional business. Small firms develop exceptional value chains that strategically configures relevant activities, marketing, and production. The idea helps to deliver a new domain with little competition. Some examples include Fargo couriers and DHL, which started using other countries' transportation and licensing services.

\subsection{Techniques of Non-Dominant Firms}

Non-dominant firms have generated several techniques and ideas that they use to dominate markets. They aim to create a normalized environment where completion is practiced by both dominant and non-dominant business organizations. In the past, most dominant firms have created market dominance by following traditional monopolizing practices. These practices limit the market access of SMEs. Others opt to increase their prices or engage in price-skimming to control a market. In this knowledgeable market economy, most firms tend to focus on ideas more than resources. Monopolizing practice is hardly effective in today's generation. Firms such as Starbucks did not grow by using monopolistic approaches, but they dominate today's market both internationally and locally [27]. Non-dominant firms tend to shift out the demand curves.

"We tend to shift out the demand curve and allow the company to offer a leap in value," explains the CEO of a firm based in the UK. For the business to be more functional in the international markets, it has to distribute resources in many markets, creating more demand from consumers [28]. A fashion and design company in Spain is trying to compete with other shoe companies in the world. Some of the competing firms are old dominant firms that issued only limited amounts and sizes of certain products. According to one owner, "if you want to beat them, offer a variety of sizes and colors in the market." Providing customers with such products will increase sales. Also, offering top-notch services, free goods exchanges, and delivery services can increase the dominance rate, even if the firm is considered an SME [29]. A pricesetting strategy is also an essential element that SMEs use to attract customers. Despite the leap value created, most nondominant firms do not set their prices high.

\section{Methodology}

The study employs a qualitative research approach; in this research, primary data is collected by conducting interviews. A total of 20 SMEs were interviewed, ten of which had already been internationalized, five were in the process of going international, and five had no plans to go abroad. Questions were answered by owners, managers, leaders, and CEOs of the firms. The collected data helped to understand, analyze, and observe the process of internationalization. It helped the researcher to understand how already internationalized businesses performed while competing with dominant firms in foreign markets, along with what local markets will experience while becoming international. The interviews 
focused on 20 leaders of SMEs, both male and female, and were conducted via email, face-to-face meetings, and via Zoom. Data were collected from July 2021 to August 2021 using the purposive sampling method. The participants completed consent forms and were informed that participation was voluntary and that the information provided was confidential and kept in a secure place. The interview questions took about 45 minutes face-to-face and less time for those who received emails. The qualitative approach asked open-ended questions to most participants. The questions were in this form because the researchers wanted to gain a deeper understanding of the research. Not all questions were expected to be fully answered; some only needed a little explanation. The questions included:

- What is your name, occupation, gender, marital status, and educational level?

- How would you describe the internationalization process?

- What strategies and techniques were used by firms when entering?

- Which entry methods were used?

- What were the motives for internationalization?

- Do you have big dreams, the desire, the need, and the ability to internationalize?

Most of the interview element was conducted online via emails and Zoom and recorded, while a few face-to-face interviews were also conducted. The data were categorized and analyzed using an Excel spreadsheet and territory help via Google Drive. The names of the participants were changed to $\mathrm{P}$, and the data was saved on a secure hard disc with a password that will be destroyed after five years (see Table 1).

\section{Findings}

\subsection{Findings}

The first interview demographic question required the participant's name and job titles. Participants were owners, managing directors, and CEOs of small firms. Selecting them helped to get clear and accurate answers to the interview questions.

"All the participants mentioned their occupation, gender, marital status, age, education level, and their country."

The second question related to how they describe the internationalization process. The interview questions were designed to investigate how the SMEs went international. Different questions asked helped identify the process and theories needed to enter outside markets.

$\mathrm{P} 9, \mathrm{P} 10$, \& $\mathrm{P} 11$ argued that the internationalization process is essentially

"Internationalization of production, the process of establishing relationship/ franchising/ licensing between enterprises of the foreign market."

Several writers had encouraged firms to enter a new market by relationship and networking, franchising, or licensing $[24,30]$. Meanwhile, P2 offered an important suggestion,

"To expand, I designed the products in a way to meet consumers in the market."

This view is supported by several writers [31]. With hesitation at the question, P3, from Oslo, Norway, stated,

"The internationalization process of the firm is a complex phenomenon that has multiple dimensions."

To conclude with this question, P5, from China, said,

"The process of internationalization should be started by acquiring vital information about the target market."

The idea is supported by Freeman and Sandwell [19]. Most of the participants agreed that the owners of small firms need to have proper strategies and techniques. P12, P13, and P15 added that,

"firms should also be successful locally to compete internationally."

Regarding question three about strategic consideration before going international in questionnaire 1, all ten firms highlighted almost the same strategies and techniques, which are an extension to less competitive primary markets, and consisted of dissemination of technology, segmentation of markets, reconfiguration of traditional business, resource development and procurement, international extension of competitor offers, and secondary market. While P16, P17, and P20 indicated,

"The need of having a strategic plan before going international" and "owners or leaders have to identify their motives for internationalization."

This submission aligns with Nwachukwu and Vu [32], who assert that SMEs must implement strategies to leverage external opportunities. In contrast, one leader interviewed, P19, indicated,

"The risk of going international and pointed out that the current market technology does not make a difference in managing the firm locally or internationally."

He added, "there is no dream, no need of moving his firm into international markets."

Question four related to which entry models were used. The question was asked to identify the most common mode that business organizations used to enter and control a foreign world. Most firms considered exporting as the primary mode of entering international markets. All ten firms interviewed agreed that,

"They joined global markets through the idea of exporting."

The method has had more reputations followed by INVs. Few firms joined international markets as wholly-owned subsidiaries [33].

The fifth question related to the motives or reasons for internationalization. Most participants who are already operating in a global market summarized their answers by saying,

"Profitability is the main motive." 
Table-1.

Describe the demographic profile of the respondents.

\begin{tabular}{|c|c|c|c|c|c|c|c|c|}
\hline $\begin{array}{l}\text { Name of } \\
\text { participants } \\
\text { replaced by codes } \\
\text { P1 - P20 }\end{array}$ & Age & Gender & $\begin{array}{l}\text { Marital } \\
\text { status }\end{array}$ & $\begin{array}{l}\text { Education } \\
\text { level }\end{array}$ & Occupation & $\begin{array}{l}\text { Years in } \\
\text { business }\end{array}$ & $\begin{array}{l}\text { Sector } \\
\text { activity }\end{array}$ & Country \\
\hline $\mathrm{P} 1$ & 29 & Female & Married & $\begin{array}{l}\text { Master's } \\
\text { Degree }\end{array}$ & Owner & 3 & Fashion & Germany \\
\hline $\mathrm{P} 2$ & 35 & Male & Single & MBA & CEO & 10 & Logistics & USA \\
\hline P3 & 50 & Male & Married & Degree & Owner & 20 & Cleaning & Norway \\
\hline $\mathrm{P} 4$ & 55 & Male & Married & Degree & Owner & 15 & Fishing & Sweden \\
\hline P5 & 27 & Female & Single & $\begin{array}{l}\text { Master's } \\
\text { Degree }\end{array}$ & $\begin{array}{l}\text { Managing } \\
\text { Director }\end{array}$ & 2 & Textiles & China \\
\hline P6 & 38 & Female & Married & Degree & Owner & 11 & Farming & Philippines \\
\hline P7 & 60 & Male & Married & $\begin{array}{l}\text { Diploma } \\
\text { Business }\end{array}$ & Owner & 30 & Cleaning & Norway \\
\hline P8 & 48 & Male & Married & Degree & Owner & 9 & Mechanic & $\begin{array}{l}\text { Congo } \\
\text { Brazzaville }\end{array}$ \\
\hline P9 & 28 & Male & Single & MBA & Owner & 2 & $\begin{array}{l}\text { Shoe } \\
\text { industry }\end{array}$ & Spain \\
\hline P10 & 39 & Male & Married & Degree & CEO & 7 & Sales & Dubai \\
\hline P11 & 41 & Male & Married & Degree & CEO & 5 & $\begin{array}{l}\text { Food } \\
\text { industry }\end{array}$ & Italy \\
\hline P12 & 43 & Male & Married & MBA & CEO & 9 & Car rental & UK \\
\hline P13 & 51 & Male & Married & Degree & $\begin{array}{l}\text { Managing } \\
\text { Director }\end{array}$ & 10 & Textiles & Singapore \\
\hline P14 & 40 & Male & Married & Degree & $\begin{array}{l}\text { Managing } \\
\text { Director }\end{array}$ & 11 & $\begin{array}{l}\text { Wine } \\
\text { industry }\end{array}$ & France \\
\hline P15 & 34 & Male & Single & Diploma & Owner & 4 & Sale goods & DR Congo \\
\hline P16 & 35 & Male & Single & A-Level & Owner & 6 & Cosmetics & Colombia \\
\hline P17 & 37 & Male & Single & Degree & $\begin{array}{l}\text { Managing } \\
\text { Director }\end{array}$ & 7 & $\begin{array}{l}\text { Const- } \\
\text { ruction }\end{array}$ & Poland \\
\hline P18 & 50 & Male & Married & Degree & $\begin{array}{l}\text { Managing } \\
\text { Director }\end{array}$ & 10 & Store & Norway \\
\hline P19 & 36 & Male & Married & Degree & Owner & 7 & $\begin{array}{l}\text { Ware- } \\
\text { house }\end{array}$ & India \\
\hline P20 & 55 & Male & Married & Diploma & Owner & 18 & Export & Brazil \\
\hline
\end{tabular}

All participants agreed that profitability is the main motive, and this is also supported by several scholars (e.g. [34, 35]). Having relationships in the specific international market could also be an important motive to start internationalization in that specific market [36].

Question six related to having a dream or desire of internationalizing their firm. P2, a CEO, mentioned the importance of having a dream or the desire to go international. P12 stated,

"No dream, no desire, forget about internationalization."

The managing director, P18, of a well-known and successful store in Oslo, Norway, stated,

"Why do we have to dream about going international? We are already successful here with a big profit, and we don't want to lose our identity, our culture, our taste, you know our store represents our ID, the way we make our sausages are unique, that is about us."

In addition to that, P7, the owner of a small cleaning firm operating in the Norwegian market for more than 100 years, stated,

"I do not have any dream or desire; really, there is no need."

Meanwhile, P8 from Brazzaville, the republic of Congo, responded to a similar question by saying, "I do have a dream, tell you plenty of dreams, but not capable, there is no support from the government, well if my firm starts moving in the global market, I will be in trouble with the authorities because I'm not from their tribes or region."

\section{Discussion}

From the findings above, the author identifies some aspects that need to be considered by SMEs both before and after entering a foreign market. All the factors and strategies mentioned in the research play a vital role in making SMEs dominate the external world. With the qualitative method used, the results were satisfactory. All consistency testing was acceptable, Although the author couldn't get satisfactory results from Congo, Africa, among others. Each member who participated in the research study had a different way of looking at the process of internationalization. They provided both traditional and modern models. Findings proved that time does not matter most when joining international markets. Those 
new organizations that join international markets undergo the same process as those that have established themselves before going international. Furthermore, the findings showed that firms that were already internationalized and those planning to go abroad had similar strategies and techniques, which helped the researcher to suggest new strategies and techniques. First, the strategies consist of three dimensions: the "big dream" or "desire," the "need," and the "ability" to achieve internationalization. After analyzing the data collected, the authors came up with this strategy according to their comprehension that for SMEs to go abroad, the owner or CEOs should DREAM BIG. This is one of the main strategies and techniques that non-dominant firms should apply to enter an international market. I believe dreaming involves holding tight to a vision of a better future, a future of success and abundance. The strategy of dreaming big associated with the desire to go international, the need to go global, and the ability to do so constitute the key strategies and techniques that nondominant owners and CEOs should start bearing in mind. They must dream of being international to become international, focus on their dreams without giving up, and their dreams of going global will become true due to this focus. The ability of a firm to internationalize has been studied as a major factor in a firm's international success. Measure planning is based on the conceptualization of organizational planning, which divides the planning process into three distinct components: budgeting, functional planning, and strategic planning. Operationalized information knowledge acquisition as a measure of the ability to internationalize based on SMEs construct measurement, developed also measured strategic and functional planning activities via independent indices and used reproduced with permission of the copyright owner. The need to internationalize is related to boosting a firm's revenue. A firm would much rather grow domestically, if possible; however, if the transaction costs of growing domestically are high due to a low available domestic market, the firm may take the option of growing through international expansion. The need to internationalize is then driven by external market factors: the size of the available domestic market, growth of the domestic market, and concentration of competitors in the domestic market. The dream to internationalize involves holding tight to a vision of a better future, one of success and abundance, the desire to put the goal into action. The desire to internationalize is related to owners' or CEOs' characteristics and whether they view the marketplace as domestic or global (managerial perceptions). The techniques consist of the diaspora social media, and RE approaches (with the idea of re-creating and re-innovating to bring something new into the targeted market), that help to use technology differently. The diaspora approach is defined, according to the English dictionary, as a large group of people who have left their homeland and have moved out to places all over the world. SME owners or managers could use the diaspora approach to connect with a country they were planning to enter. The best use of the diaspora approach could help to gain a large market and gather genuine information about the country; diaspora connects people, communities, projects, and languages and, more significantly, unites people to achieve a set goal. The diaspora approach can help owners and managers of SMEs cooperate with other firms around the world and can be used as a faceto-face connection for small businesses planning to enter the international market. Social media has become an important element today, especially during the coronavirus pandemic, as the main part of marketing for firms or businesses of all sizes. Social media has become a key tool for connecting with millions of people around the world: it could be a technique for entering an international market. The social media goal of non-dominant firms is to provide content that is relevant for new potential customers or partners. It can also help SMEs reach multicultural people and connect directly with the land they are planning to enter. Social media is a modern way for a firm to be visible around the world, and the best way to interact with other firms already in an international market, in which SME owners could share, exchange, and create ideas or projects. The third approach, the RE approach, represents re-create, re-launch product, re-price, re-design, re-focus, etc. For example, re-pricing is a technique where product prices are continuously adjusted to gain the market into which the firm is planning to move. This technique has the potential to affect another firm in the market. Many firms use these techniques to boost their sales (e.g., Amazon). In this study, non-dominant firms might use this technique when entering a new market, for example, offering two quality items for the price of one. Furthermore, re-launching products or enterprises could be used as a technique to enter an international market. It could help customers be curious and excited to know what is new in the market, give an impression of premium products and create awareness. The authors propose a strategytechnique model for the internationalization of non-dominant firms, as in Figure 1.

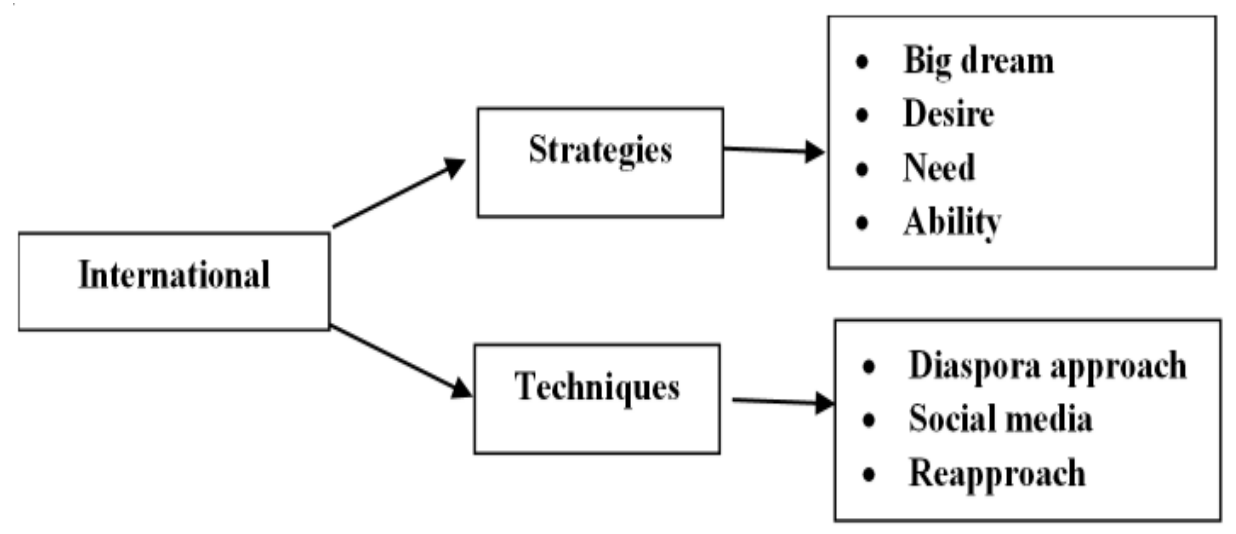

Figure-1.

Proposed Strategy-Techniques Model for Internationalization (developed by authors). 


\section{Conclusion}

\subsection{Conclusion}

In recent decades, many developing countries have been linked to a strong role in the development and internationalization of SMEs. Most firms that are internationalized and dominate international markets use theoretical factors aspects to go abroad. The findings showed that SMEs could internationalize their firms by having adequate strategies and techniques. The results also showed that not all non-dominant firms can afford an internationalization process due to the lack of big dreams, ability, and need. Some owners or leaders do not have the vision or desire to move their business into a global market due to the absence of internationalization knowledge and expertise. Further, the world is changing so fast that the results indicated the need for new strategies and techniques to meet the requirements imposed by the environmental change. Finally, the results demonstrated that there are important factors to consider before entering a new market.

\subsection{Managerial Implications}

The strategies and techniques used by non-dominant firms to join and dominate international markets have provided a stable business model in foreign markets. The study provides useful and relevant business knowledge to SMEs on expanding into international markets. The study proposes that for SMEs to participate and dominate in international markets, the owners should consider certain factors. Leveraging leadership skills, dreaming big, and having the desire to go international are significant factors for international market success. As such, top priority should be accorded to these factors by SME owners and managers.

\subsection{Study Limitations and Suggestions for Further Research}

This research has some limitations. First, the coronavirus pandemic makes face-to-face data collections difficult. Second, the geographical location of the firms made interviewing and collecting data challenging. Numerous activities prevented the collection of data. Some details, such as operational costs, were not included in the research. The research primarily focused on market mode and partner selection, although there are other aspects to consider. From the research provided, additional information is needed to determine the strategies and factors that make non-dominant firms control dominant firms. It is essential to investigate the internationalization process of SMEs in different countries separately to uncover the systems and methods needed for a new firm to go international. It would be better to categorize the SMEs into stages and groups to explain their behaviors. The research tends to recommend more face-to-face interviews and analysis to acquire data of greater quality and reliability. The study delivered several statements regarding the process and adaptations of the SMEs. Future researchers should be able to connect the research findings to important elements and models. They should focus on the preventive changes that will enable SMEs to internationalize. Further studies can explore strategies and techniques of non-dominant businesses using other qualitative research approaches such as case studies or participant observation.

\section{References}

[1] B. Guillotin and V. Mangematin, "Internationalization strategies of business schools: How flat is the world?," Thunderbird International Business Review, vol. 57, pp. 343-357, 2015.

[2] G. F. Jiang and G. L. Holburn, "Organizational performance feedback effects and international expansion," Journal of Business Research, vol. 90, pp. 48-58, 2018.

[3] S. T. Cavusgil and G. Knight, "The born global firm: An entrepreneurial and capabilities perspective on early and rapid internationalization," Journal of International Business Studies, vol. 46, pp. 3-16, 2015.Available at: https://doi.org/10.1057/jibs.2014.62.

[4] A. Calabrò, G. Campopiano, R. Basco, and T. Pukall, "Governance structure and internationalization of family-controlled firms: The mediating role of international entrepreneurial orientation," European Management Journal, vol. 35, pp. 238-248, 2017.Available at: https://doi.org/10.1016/j.emj.2016.04.007.

[5] S. A. Zahra and G. George, "Absorptive capacity: A review, reconceptualization, and extension," Academy of Management Review, vol. 27, pp. 185-203, 2002.Available at: https://doi.org/10.5465/amr.2002.6587995.

[6] H. M. Vu and C. Nwachukwu, "Influence of entrepreneur competencies on profitability and employee satisfaction," International Journal of Management and Enterprise Development, vol. 20, pp. 1-16, 2021.Available at: https://doi.org/10.1504/ijmed.2021.10036187.

[7] H. H. Stevenson and J. C. Jarillo, "A paradigm of entrepreneurship: Entrepreneurial management," Strategic Management Journal, vol. 11, pp. 17-27, 1990.

[8] C. Nwachukwu. and M. H. Vu, "Entrepreneurial leadership, turnover intention and profitability Nexus," Journal of Legal Ethical and Regulatory, vol. 24, pp. 1-12, 2021.

[9] J. Wood, "Globalization and business masculinities," Men and Masculinities, vol. 7, pp. 347-364, 2005.

[10] O. Kyvik, "The global mindset: A must for international innovation and entrepreneurship," International Entrepreneurship and Management Journal, vol. 14, pp. 309-327, 2018.

[11] P. T. H. An, "Trade credit and performance of food production companies in Vietnam," International Journal of Management and Sustainability, vol. 10, pp. 52-68, 2021.Available at: https://doi.org/10.18488/journal.11.2021.102.52.68.

[12] P. Lasserre, Global strategic management, 4th ed. UK: Palgrave Macmillan, 2017.

[13] M. Revindo, C. Gan, and C. Nguyen, "Internationalization strategy and process: Evidence from Indonesian SMEs," World, vol. 8, pp. 59-74, 2017.Available at: https://doi.org/10.21102/wjm.2017.03.81.05.

[14] S. Abdo and D. Edgar, "Facing the challenges of Covid-19 in the Egyptian banking sector: The role of bricoleurs in achieving organizational innovations via learning through improvisation," Journal of Social Economics Research, vol. 8, pp. 77-95, 2021. 
[15] K. D. Brouthers, K. D. Geisser, and F. Rothlauf, "Explaining the internationalization of ibusiness firms," Journal of International Business Studies, vol. 47, pp. 513-534, 2016.Available at: https://doi.org/10.1057/jibs.2015.20.

[16] M. A. Boermans and H. Roelfsema, "Small firm internationalization, innovation, and growth," International Economics and Economic Policy, vol. 13, pp. 283-296, 2016.Available at: https://doi.org/10.1007/s10368-014-0310-y.

[17] C. F. Fey, A. K. Nayak, C. Wu, and A. J. Zhou, "Internationalization strategies of emerging market multinationals: A five M framework," Journal of Leadership \& Organizational Studies, vol. 23, pp. 128-143, 2016.

[18] M. Couto and J. J. Ferreira, "Brand management as an internationalization strategy for SME: A multiple case study," Journal of Global Marketing, vol. 30, pp. 192-206, 2017.Available at: https://doi.org/10.1080/08911762.2017.1307477.

[19] S. Freeman and M. Sandwell, "Professional service firms entering emerging markets: The role of network relationships," Journal of Services Marketing, vol. 22, pp. 198-212, 2008.Available at: https://doi.org/10.1108/08876040810871165.

[20] C. V. Martincus and J. Carballo, "Entering new country and product markets: Does export promotion help?," Review of World Economics, vol. 146, pp. 437-467, 2010.Available at: https://doi.org/10.1007/s10290-010-0062-x.

[21] G. Dedes, M. Golias, C. Douligeris, and S. Mishra, "Challenges, risks and opportunities for connected vehicle services in smart cities and communities," IFAC-PapersOnLine, vol. 51, pp. 139-144, 2019.Available at: https://doi.org/10.1016/j.ifacol.2019.01.056.

[22] A. N. Hoffman and C. E. Bamford, Strategic management and business policy vol. 55. Boston, MA: Pearson, 2017.

[23] S. Mariotti and R. Marzano, "Varieties of capitalism and the internationalization of state-owned enterprises," Journal of International Business Studies, vol. 50, pp. 669-691, 2019.

[24] J.-M. G. Geleilate, R. Parente, K. Rong, and E. Misati, "Adapting and sustaining operations in weak institutional environments: A business ecosystem assessment of a Chinese MNE in Central Africa," Journal of International Business Studies, vol. 50, pp. 275-291, 2019.Available at: https://doi.org/10.1057/s41267-018-0179-z.

[25] L. Takala-Greenish and D. Guizzo, "Teaching to think: challenges and suitability of teaching inequality topics in a business school," International Journal of Pluralism and Economics Education, vol. 9, pp. 106-127, 2018.Available at: https://doi.org/10.1504/ijpee.2018.10013524.

[26] S. Glozer, L. Spence, A. Crane, and D. Matten, Business ethics: Managing corporate citizenship and sustainability in the age of globalization. USA: Oxford University Press, 2019.

[27] C. I. Nada and H. C. Araújo, "'When you welcome students without borders, you need a mentality without borders' internationalisation of higher education: Evidence from Portugal," Studies in Higher Education, vol. 44, pp. 1591-1604, 2019.Available at: https://doi.org/10.1080/03075079.2018.1458219.

[28] W. Newburry, N. A. Gardberg, and J. I. Sanchez, "Employer attractiveness in Latin America: The association among foreignness, internationalization and talent recruitment," Journal of International Management, vol. 20, pp. 327-344, 2014.

[29] W. Chan, T. K. Ng, and K. W. C. Wang, "Acculturation and cross-cultural adaptation: The moderating role of social support," International Journal of Intercultural Relations, vol. 59, pp. 19-30, 2017.Available at: https://doi.org/10.1016/j.ijintrel.2017.04.012.

[30] H. Gholizadeh, H. Fazlollahtabar, and M. Khalilzadeh, "A robust fuzzy stochastic programming for sustainable procurement and logistics under hybrid uncertainty using big data," Journal of Cleaner Production, vol. 258, p. 120640, 2020.Available at: https://doi.org/10.1016/j.jclepro.2020.120640.

[31] G. Alberti and F. E. Iannuzzi, "Embodied intersectionality and the intersectional management of hotel labour: The everyday experiences of social differentiation in customer-oriented work," Gender, Work \& Organization, vol. 27, pp. 1165-1180, 2020.Available at: https://doi.org/10.1111/gwao.12454.

[32] C. Nwachukwu and H. M. Vu, "Strategic flexibility, strategic leadership and business sustainability nexus," International Journal of Business Environment, vol. 11, pp. 125-143, 2020.Available at: https://doi.org/10.1504/ijbe.2020.107500.

[33] U. Andersson, D. B. Holm, and M. Johanson, "Opportunities, relational embeddedness and network structure. In Managing opportunity development in business networks," ed London: Palgrave Macmillan, 2005, pp. 27-48.

[34] S. Hollensen, Global marketing - a-decision oriented approach, 5th ed. Harlow: Pearson Education Limited, 2011.

[35] N. Nummela, "Change in SME internationalization: A network perspective. International Growth of Small and Medium Enterprises," ed New York: Routledge, 2011, pp. 248-26.

[36] I. Kujala and R. A. Owusu, "The internationalisation of African emerging market SMEs - a literature review and propositions," The Market: International Journal of Business, vol. 2, pp. 98-109, 2021. 